\title{
Grammar Translation Method: Current Practice In EFL Context
}

\author{
Milawati \\ Politeknik Negeri Madura, Indonesia \\ milawati@poltera.ac.id
}

\begin{abstract}
:
This paper reports the findings of a case study investigating Grammar Translation Method (GTM) through mother tongue, much-isolated words, and putting words together in grammar class to scaffold students' learning. Mixed methods, classroom observations, field-notes and videotape recording, were employed to collect the data. The data gained, then, transcribed and classified by using code. The selected data is displayed into table and analyzed descriptively. While validating data is done by crosschecking the result of data analysis of each methods. The data is reported in regard with the result of findings and discussion to answer the research questions of this study. Findings indicate that among three types of GTM, the use of mother tongues was frequently used to give instruction. Other findings show that much-isolated words were used to introduce new vocabulary, and putting words together were used to explain topic discussion. Some changes to create effective GTM through other types of GTM was also discussed.
\end{abstract}

Keywords: grammar-translation method, isolated words, mother tongue

\section{Introduction}

Though it is a traditional method, Grammar Translation Method (GTM) is still frequently used by EFL teacher though many new inovative methods have apperared. in some countries where English as foreign language. Some EFL teachers perceive that among the language teaching methods, the Grammar Translation Method is the easiest method for the English teacher to achieve their target language through the importance of vocabulary and grammar rules. It is in line with Richards (2002) posses a first language as a basic approaches to acquire the grammar rules of their target language. It indicates that Grammar Translation Method requires the students to know the syntax and apply the grammar knowledge in translating.

In EFL context where teaching grammar is dominated by a grammar-translation method, the EFL teacher tends to be more focus on the accuracy of their students' competence, rather than their performance. In Indonesia, for instance, grammar translation method was mostly used by the EFL teacher in teaching reading, compared to the use of the direct method (Hermita, 2009). While in Jordan, the government policy suggested the EFL teacher to translate the target 
language into their native language whenever the students face difficulties in acquiring their target language in classroom (Aqel, 2013). Other reason, like, the belief of some EFL teacher toward the power of translation as a tool which could make the students intensively acquire their target language (Dagilience, 2012; Mart, 2013). It is also becoming a preferable method for EFL to enhance students' competence and performance effectively, especially EFL students' in a basic level (Al Refaai, 2013). Some studies also prefer to combine between Grammar translation method and Communicative approach to improve the students' accuracy and fluency in acquiring their competence and performance in EFL classroom (Chang, 2011; Mondal, 2012). Moreover, Chang (2011) in his contrastive study in investigating GTM in EFL class found that the EFL teacher provided learners the grammar rules and examples. It aimed to memorize them and then asked them to apply the rules to other examples. Another study in EFL context in Indonesia was also done by Elmayanthie (2015) in her study focusing on reading text, which showed nine major patterns of GTM applied: using mother tongue, teaching isolated words, putting words together, focusing on the form and inflection of words, teaching the difficult reading in early-stage; (6) ignoring the content of the text; (7) translating to drill students; (8) ignoring pronunciation; and (9) focusing on accuracy.

In accord with the previous studies above, it could infer that mother tongue posses as a crucial factor to acquire the meaning of target language in translation (Thornbury, 2002; William, 2005). Similarly, it is also happened in EFL context in Indonesia recently. The result of a preliminary study in one of State Senior High School in Bangkalan was found that the English teacher still used Grammar Translation Method for teaching grammar in the learning process. She was preferably to employ Grammar Translation Method to make students understand grammar. However, differently from those previous studies, this study investigates the detail implementation of Grammar Translation Method in grammar class, by employing three strategies namely the use of mother tongue, the grammar rules through its examples, and apply the rules to other examples, proposed by Brown (2001:18-19) under consideration that those strategies were frequently found during the preliminary study done in collaboration between the researcher and the subjects.

\section{Literature Review}

Teaching grammar has been regarded as important in the learning process of a language because grammar is the system of a language. Even, people sometimes describe grammar as the rules of a language. Grammar expands its distinction in language teaching, particularly in English as a foreign language (EFL). In consequence, grammar is too important to be ignored because, with grammar, learners' language development will be controlled (Richards et al, 2002:145). It is also suggested to the teacher to teach certain grammar points in the pre-activity of teaching when it is predicted that the students will face difficulties in skill activities. In post activity, teachers correct the errors by sparing some time before the class ends when the teacher find grammar errors during the skill (Fachrurrazy, 2011:95-97).

Brown (2001:18-19) explained that there are 8 principal characteristics of the GrammarTranslation Method. First, class is taught in the mother tongue, with little active use of the target language. It means that the teacher uses the native language to help student to understand the material given in grammar lessons. For instance, English teacher in Indonesia uses Indonesian for her/his instruction. Target language is a part of translation. According to Larsen (2000) "Translation consists of translating the meaning of the source language to a target language." The 
position of mother tongue is as same as the first language. Thus, by using grammar translation method teachers apply her or his first language as a media of instruction in teaching. It is related to the statement of Richards et al (2002:4) that "The students' native language is the medium of instruction." In addition, native language is used to explain new items and to enable comparisons to be made between the foreign language and the mother tongue.

Second characteristics, that is vocabulary, is taught in the form of lists of isolated words. To achieve the kinds of learning targets, vocabulary learning is needed to be learned by students (Thornbury, 2002:32). For example, the teacher introduces things in the classroom and asks the students to translate them into English or the teacher writes some Indonesian words and asks the students to translate them into English. Without a vocabulary, it is hard to develop teaching approaches or pedagogies that are effective (Moseley, 2005:1). It means that the teacher tries to introduce some vocabulary in material to make teaching successful. It is also supported by Fachrurrazy (2011:97), who stated that part of speech is a verb, adjective, adverb, article, preposition, etc, which are also parts of vocabulary related to a topic-focused. Thus, learners are not difficult to understand the material.

\section{Research Methodology}

This study has employed a qualitative approach as a research design (Cresswell, 2012, p.465). The qualitative study attempts to explore in detail the use of grammar translation methods which The English teacher used in grammar class. An English teacher and one class in the eleventh grade were chosen as a research subject. She is one of senior English teachers who has been teaching in that school, for about 11 years. She also frequently talks more in her class. It can be seen in the way she teaches in her classroom, she explains more or very often gives a tutorial to the students. This research was conducted in one of state senior high school in Bangkalan. The observation has been done in five meetings. A non-participant observer was chosen to record notes without becoming involved in the activities of the participants.

The data has taken in the form of utterances, the researcher uses fieldnote and audiotape recording in collecting the data. Fieldnote is used to notice non-verbal The English teacher's behavior. This study has applied triangulation dealing with the methods of data collection. It employed non-participant observation to gain the data. In this case, there are two kinds of data; data get from the result of fieldnote and audiotape recording. Purposefully, the non-participant observation has occasionally conducted for about five meetings.

The data has been analyzed through some procedures proposed by Miles and Huberman (1994:10-12). The procedure consists of three current flows activity: data reduction, data display, and conclusion drawing/verification. In particular, some steps have been conducted in analyzing the data which cover the following activities. (1) aggregating the data gathered, involving all of the information from the field. In this case, the data obtained were processed by transcribing The English teacher's utterances gained by the result of audiotape recording during the advanced prose class was conducted. (2) classifying the data gained by the result of recording transcription. Those were classified in terms of the Grammar Translation Method proposed by Brown (2001). The code of Grammar Translation Method such as Mother Tongue (MT), Vocabulary (VC), Rules Putting Word Together (RPWT). (3) displaying the data which has been selected and simplified to make it clearer and easier to be interpreted. (4) interpreting the data which analyzed descriptively; (5) validating the data, the results of data analysis from 
transcription were crosschecked out with the data from the result of field-notes to validate the findings; (6) reporting the result, making the conclusion, which were derived in regard with the result of findings and discussions to answer research questions.

\section{Findings}

Grammar Translation Method is almost used in EFL classes to acquire their trget language. Based on the data found, three major characteristics are found when The English teacher taught grammar in grade XI. They are the use of mother tongue, the use of much of vocabulary in the form of isolated words, and the use of rules of putting words together.

It was found that the English teacher used fifty-five utterances of mother tongues for three cases; for giving general instruction, introducing past tense, and introducing modal perfect. Twentyfive new vocabularies in the form of isolated words for many cases in which The English teacher mainly introduced the vocabulary of an irregular verb, verbs, adjective, modal, and noun. There were also found that three utterances in the rule of putting words together when explaining past tense.

\subsection{Mother Tongue}

Based on the result of the observation, it was found that the English teacher switches her English language into Indonesian under the situation when she gave general instruction, explained about tenses such as simple past tense, and modal perfect as described below.

\subsubsection{Teacher Used Mother Tongue for Giving General Instruction}

In the dialogue below, The English teacher gave general instructions to ask students to search the kind of tenses in the paragraph. The English teacher asked by using English utterances and translated it to the Indonesian language.

MT.1)T: "Thank you, ok I ask you, how many kinds of tenses here? Ada berapa macam tenses di paragraph ini(how many tenses in this paragraph), how do you know"

S6: "Banyak, lebih dari satu," (too many, more than one)

Based on dialogue above, The English teacher used mother tongue to ask for kind of tenses to the whole students because students will be more understand the instruction. Sometimes students did not do the instruction from The English teacher because they did not understand the instruction if it is delivered by using English utterance.

\subsubsection{Teacher Used Mother Tongue in the Case of Introducing Past Tense}

The English teacher used mother tongue to facilitate the student in learning new tenses. The introduction of the new tenses needs mother tongue as a media to make the communication between the English teacher and students runs easier. In the dialogue below, The English teacher gave the mother tongue to make students know which sentence that used past tense in the paragraph. The English teacher tried to give an early introduction of past tense related to the narrative text which is read by students.

MT.18) T : "Past Tense? Yang mana yang Past Tense?"(Which one is past tense)

MT.19) $\mathrm{T}$ : "Tenses nya apa disitu tadi?(what tense is used?)// yang pertama (the first one) (.) kalau Narrative pakai apa?(if it is narrative, which tense will you use?) 
In the utterance above, The English teacher began introducing past tense without entered to the main content, because The English teacher wanted to bring students to recognize past tense sentences first. In grammar, it can be called inductive procedure. As Fachrurrazy (2011: 95) stated that the inductive procedure is introducing examples first and then making rules. It is related to the utterance that The English teacher made the students understand by asking students to find a sentence of past tense and then it is followed by explaining the rules.

Besides, below, The English teacher gave an example of a past tense with a combination of subject, verb, object, and complement. The English teacher also explained the complement and time signals of the past tense.

MT.25) T : "Oke buat sekarang kalimatnya (Ok, could you write the sentence?)(.) sama seperti ini(the same to this) (.) Papi Rosi loved Wulan jadi ada subject, ada predikat, dan object, kalau misalkan ada keterangan waktu silahkan, apa biasanya keterangan waktunya, pakai apa?" (PapiRosi loved Wulan, So there is a subject, predicate and the object. If there is an adverb of time, what time signal will you use?)

MT.26) $\mathrm{T}$ : “This morning, pakai apa lagi ((pause)) keterangan waktu”(this morning, then what else?)

S26 : "Yesterday"

The utterance above indicated that the English teacher explained the example of past tense with the explanation of subject, verb, and object and complement. The English teacher substituted the word 'verb' with 'predikat'. The English teacher used the mother tongue to make students understand the meaning of the verb.

\subsection{Teacher Used Mother Tongue in Cases about Introducing Modal Perfect}

In addition to the usage of the mother tongue for introducing tenses, the mother tongue can also be used to introduce other parts of grammar that is a modal perfect sentence. The English teacher tried to use the mother tongue to explain modal verbs, the rules of the sentence, and the example of the modal perfect sentence.

Here, The English teacher used the mother tongue for explaining modal perfect. The English teacher asked students to read a paragraph and she translated the meaning of the sentence that was read by students. When students read the rule of modal perfect, The English teacher always explained each sentence and asked students to continue the sentence. For example, the dialogues were:

MT.33) $\mathrm{T}$ : "Ya tu modal Tapi nominal (.) selaindari kata Kerja, next terus"(yes, that's modal but in the form of a noun, what else, next)

S1 : "Subject + Modal + Have + V3 + ..."

MT.34) $\mathrm{T}$ : "Yes kalimat aktif seperti biasaya, menggunakan verb 3, trus"(Yes, the sentence usually uses verb 3, next)

MT.38) $\mathrm{T}$ : "Should ought to (.) write down sebelahnyaya,(write down, on next to) // something to be done in the past berarti sesuatu yang dikerjakan di masa lampau, jadi penggunaan should disitu apa artinya should?"(something to be done in the past, means something has been done previously, so what it means by "should'?) 


$$
\text { S7 : "Akan"(Will) }
$$

In the dialogue above, The English teacher explained the usage of modal 'should'. But, the students gave the wrong answer, and it is the role of the English teacher to correct it. It is related to Larsen (2000:17) stated that "The English teacher is the authority in the classroom. Students must get the correct answer." It means that The English teacher should correct what students do if it is wrong, to reach successful learning.

\subsection{Much Vocabulary in the Form of Isolated Words}

The result of the observation found that The English teacher used much vocabulary in the form of isolated words under the situation when she introduced a new vocabulary like an irregular verb, regular verb, adjective, modal and noun as described below

\subsubsection{The English teacher Introduced New Vocabularies of Irregular Verb}

In the dialogue below, The English teacher touched an explanation about irregular verbs in the teaching-learning process. It is related to Larsen (2000:17) said that "Students have to memorize Present Tense, Past Tense, and Past Participle forms of one set of irregular verbs." The dialogues were:

\footnotetext{
VC.1) T : "Knew ((pause)) knew Dari kata apa,"(the word 'knew' derived from?)

Ss : "Know"

VC.2) T : “Became, dari kata apa tu?” ('Became' derived from?')

S5 : "Become miss, a wise and just king again"

VC.3) $\mathrm{T}$ : "Tulis dulu rumusnya. Oke finish sudah. Itu semua di dalam kurung ubah ke V3.Diubah jadi apa tu give? Kalo give berubah jadi apa?"(Please write the pattern first. The all the verbs the parentheses change into V3. So 'give' will change into?)

S24: "Given"

VC.4) T : “Get nya berubah jadi apa V3?”('Get' will change into..?)

S19 : "Got"
}

The English teacher asked verb 1 of 'became' and 'knew' in teaching past tense. The English teacher also asked the V3 of 'give' and 'get'. An irregular verb is one of the fundamental parts of tenses. The purpose of the English teacher gave the new vocabularies of irregular verbs is to increase the student's knowledge about the variety of regular and irregular verbs.

\subsubsection{The English teacher Introduced New Vocabularies of Verbs}

In the dialogue below The English teacher asked students to answer the meaning of 'ask' in the mother tongue. It is related to the topic of modal perfect.

VC.10) $\mathrm{T}$ : "He washed his clothes instead of having his servant do it last Sunday (.) diam encuci pakaian sendiri meskipun dia punya pembantu. He bla bla bla his servant do it if he had wanted to do. Apaitu? Pasti ia bisa . . apa itu artinya ask" (so, what does 'ask' mean?) S30: "Meminta"

The utterance above described how The English teacher asked the meaning of vocabulary 'ask'. The English teacher asked students because The English teacher tried the knowledge of students, that they have been known the meaning of 'ask' or not. 


\subsubsection{The English teacher Introduced New Vocabularies of Adjective}

In the dialogue below, The English teacher taught the vocabulary of adjective words like 'foolish', 'hard', and 'difficult'. The dialogues were:

VC.11) T : "Foolish tu apa ((pause) foolish ((pause)) foolish ((pause))" (what does 'foolish' mean?)

S5 : "Fulus"

VC.12) $\mathrm{T}$ : "Yak disimpulkan (.) Ketika saya bangun pagi di jalan dan juga pohon semua pada basah. Nah ini artinya pasti kan gak mungkin Rizal nyiram pohon tu sudah pasti hujan. Hard, apa itu // hard?"(conclude. Suppose that you were walking under the tree, but the tree is getting wet. So it doesn't mean that rizal has watered the tree, but it is getting because of the hard rain, so what is 'hard'?)

Ss : "Deras"

VC.13) $\mathrm{T}$ : "Karena gak ada V3 nya (.) difficult test, difficult kata apa?"(because there is no v3 form, 'difficult' is classified as')

S13 : "Kata sifat"(adjective)

Based on the dialogues above, The English teacher asked the meaning of vocabularies of 'foolish', 'hard', and 'difficult' to increase the knowledge of students. Students should know the adjective because sometimes adjective is used in a sentence of English.

\subsection{The English teacher Introduced New Vocabularies of Modal}

In the dialogue below, The English teacher asked the meaning of vocabulary of modal perfect, consist of should and shall. The dialogues were:

VC.16) T : "No, should disituapa // artinya”" (shoud, what does it mean?)

S8 : "Seharusnya"

VC.17) T : Anam, (.) baca could, could. Kalau should tadiartinyaapa, should"(so, what does it mean by 'should'?)

Ss : "Seharusnya."

VC.18) T : "Jadi should samadengan ought to dari kata apa // ni should?" (so 'should' has the same meaning to 'ought to'. So what 'should" derive from?)

S10 : "Shall"

The dialogue above showed that the purpose of the English teacher gave the meaning of vocabulary 'should' is to make students knew the fundamental part of modal perfect, it is about modal, before students would be taught about the application of modal perfect.

\subsubsection{The English teacher Introduced New Vocabulary of Noun}

Although students usually have known many nouns around them, The English teacher sometimes explains the strange vocabularies of a noun. The following is the dialogue shown that The English teacher asked the meaning of the noun to explain noun to students. The English teacher asked the meaning of vocabulary 'chemistry'.

VC.25) T : "Must, ayo perhatikan dulu. ((pause)) The students usually do the test well. Murid-murid biasanya mengerjakan test dengan baik ((pause)) But they 


$$
\begin{aligned}
& \text { couldn't do the chemistry, mereka tidak dapat mengerjakan chemistry, apa } \\
& \text { itu chemistry? (what does it mean by 'chemistry'?) } \\
& \text { Ss : "Kimia" }
\end{aligned}
$$

In the data above, The English teacher taught nouns like 'chemistry' to enlarge the knowledge of students. If the students know more vocabulary, the students will have larger knowledge.

\subsection{Rules of Putting Word Together}

The English teacher put the word together when she explained about simple past tense. Particularly, she explained about the characteristics, the time signals, and the way how to form a sentence of the tenses, either in positive, negative, and interrogative. Because of the subtopic is Past Tense, the English teacher in this dialogue explained the rule of past tense, as it is described below:

RPWT.1) T : “Ok, Subject + Verb $2+$ Object. Now you must make sentence by using this verb loved, called, died, and cut, buat kalimat dari kata itu yo, semua kerjakan,"

S24 : "Bu, sekarang // tinggal dua lembar"

Based on dialogue above, The English teacher gave the rule of past tense. The English teacher said that the combination of Subject + Verb 2 + Object can form a positive past tense sentence. The English teacher used the rule of the past tense to make students easier in understanding past tense.

\section{Discussion}

The result of this study revealed that three strategies in the grammar translation method proposed by Brown (2001) were employed by The English teacher during five meeting observations. There were fifty-five utterances with mother tongues which are used by the English teacher in teaching-learning grammar, twenty-five new vocabularies that are introduced during teaching-learning grammar, and three utterances showed that The English teacher used rules putting words together.

Mostly The English teacher used mother tongue as a medium of instruction when she explained new items and enable comparisons to be made between the foreign language and the mother tongue. Directly, students will translate the sentence into the Indonesian language. In that way, it could prove that translating their target language into their mother tongue could benefit students to understand the grammatical rules easier (Chang, 2011; Aqel, 2013; Elmayanthie, 2015). As a result they could acquire the correct answer. Though the GTM works well in enhancing students' grammar, but in this study still found that the students faced difficulties in implementing their grammar in communication (Chang, 2011). Perhaps, it happens because the interaction during the grammar only one way communication which is dominated by teacherstudent interaction.

In addition to vocabulary was also play important roles in grammar translation method. In this case, The English teacher taught irregular verbs as a variation of a verb which is used in tenses. This kind of verb frequently found to enable students to understand easier. This is in line with what Natsir and Sanjaya (2014) investigated in implementing GTM, students should enrich their vocabularies, indeed they need to be familiar with certain vocabularies within their daily context to make them easier to understand their target language through grammar. 


\section{Conclusion}

Grammar Translation Method provides students to translate sentences directly for practicing translation and learning the application of tenses at once. The three strategies of GTM namely mother tongue used, rich vocabulary, putting the word together are inseparable to reach successful learning goal. The mother tongue as a crucial factor in scaffolding student to understand the material given in grammar lessons. Meanwhile, they also need a rich vocabulary and the strategy on how to put words together in the order they could achieve their learning targets.

\section{Acknowledgments}

This research was funded by DIPA Politeknik Negeri Madura. It is a month pilot project in collaboration with The Education authorities in Bangkalan, especially the head of State Senior High School in Bangkalan.

\section{References}

Al Refaai, K.I. (2013). Suggested Guidelines for Using Translation in Foreign Language Learning and Teaching. Educational Research. Internasional Research Journal, 4(1) Pp 12-20

Aqel, I.M. (2013). The Effect of Using Grammar Translation Method on Acquiring English as a Foreign Language. International Journal of Asian Social Sciense, 3(12) pp. 2469-2475

Brown, H. Douglas. (2001). Teaching by Principles an Interactive Approach to Language Pedagogy $2^{\text {nd }}$ ed. Pearson ESL Addison-Wesley Longman http://let590.files.wordpress.com/2013/01/teaching-by-principles-douglas-brown.pdf accessed on December $28^{\text {th }}, 2018$

Chang, Shih-Chua.(2011). A Contrastive Study of Grammar Translation Method and Communicative Approach in Teaching English Grammar. ELT Journal, 4(2), Pp. 13-24

Cresswell, J. W. (2012). Educational Research; Planning, Conducting, Evaluating Quantitative and Qualities Research $4^{\text {th }} \mathrm{ed}$. London: Pearson Education Inc.

Dagilience, I. (2012). Translation as a learning method n English Language Teaching. Studies about Languages, 2(1), Pp. 124-129

Elmayanthie. (2015). The Use of Grammar Translation Method in Teaching English. Journal on English as a Foreign Language, 5(2), September 2015

Fachrurrazy. (2011). Teaching English as a foreign language for teachers in Indonesia. Malang: State University of Malang Press.

Hermita, Yesica. (2009). "Grammar Translation Method and Direct Method in Teaching Reading at LPIA Margonda Depok (A Comparative Study)". http://www.gunadarma.ac.id/library/articles/graduate/letters/2009/Artikel_10605132.pdf, accessed on January $2^{\text {nd }} 2018$

Larsen, Diane and Freeman. (2000). Techniques and Principles in Language Teaching $2^{\text {nd }}$ ed. London: Oxford University Press

Mart, Chagri Tugrul. (2013). The Grammar Translation Method and The Use of Translation to Facilitate Learning in ESL Classes. Journal of Advance in Elnglish Languae Teaching, 1(4).pp. 103-105 
Miles, M. B., \& Huberman, A. M. (1994). Qualitative Data Analysis An Expanded Sourcebook. Thousand Oaks, CA Sage Publications.

Mondal, K.N. (2012). English Language Learningn through the Combination of Grammar Translation Method and Communicative Languge Teaching. Academia Arena, 4(6) Pp. 20 24

Moseley. (2005). Learning styles and pedagogy in post-16 learning: a systematic and critical review. London : Learning \& Skills Research Centre

Natsir, M and Sanjaya, D. (2014). Grammar Translation Method (GTM) versus Communicative Language Teaching (CLT); A review of literature. International Journal of Education and Literacy Studies. 2(1), pp 58-62.

Richards, Jack. C., Renandya, Willy.A., (2002). Methodology in Language Teaching an Anthology of Current Practice. New York: Cambridge University Press

Thornbury, Scott. (2002). How to Teach Vocabulary. Malaysia: Pearson Education Limited

Williams, James. D. (2005). The English teacher's Grammar Book $2^{\text {nd }}$ ed. New York: Lawrence Erlbaum Associates 